UDC 338

\title{
POLITICAL ECONOMY OF THE FINANCE WITHIN THE EXPECTATION OF INDONESIAN DEMOCRATIC ERA
}

\author{
Mustofa Mochamad Ridwan ${ }^{1 *}$, Putra Ahmad Bakri ${ }^{1}$, Suraji ${ }^{1,2}$, Embi Muhammad $\mathrm{Ali}^{3}$ \\ ${ }^{1}$ Ghazali Shafie Graduate School of Government, Universiti Utara Malaysia, Malaysia \\ ${ }^{2}$ University of Hangtuah Surabaya, Indonesia \\ ${ }^{3}$ College of Law, Government and International Studies, Universiti Utara Malaysia, Malaysia
}

*E-mail: $\underline{\text { mridwanm@gmail.com }}$

\begin{abstract}
The effort to determine the appropriate formulation in the determining of financials is the financial forward to whom and how is to actualize it? Thus the finance should have dimension on the justice. Furthermore, the finance of political economy certainly will closely relate to the effort of the state and government to give any appropriate social guarantee to the people especially to the people under the poverty line. The pattern of the relationship of which transparent, accountable, democratic between the government with the people and the prejudice will prevent while the state/government/legislation able to conduct the good process and profitable toward the society and not the officials. The finance also could be perceived as the political perspective whereas it could be translated as the state guarantee to struggle the social finance of which more prioritized rather than the official expenditures finance or the given institutions. Thus the political and economical context of finance will relate with whoever have role and ability in state in giving guarantee toward its society. However in fact the political economy is perceived and conducted in short term context and only bring profit to the related parties. The regulation in the program determination is only lies on the level of mutual interest of the actor, whereas the society often does not know the process and the participation in determining to what extent the process which happened. Even the society does not know how many percent of the finance to be granted to their prosperity. Related to the analysis of political economy in the finance are the certain in the study of social knowledge because the political economy used the supradisciplinary approach. The focus of this analysis is on every issue or obligation, of which directly or indirectly involving the public interest and also in a great number of their consideration to be granted in the problems relate to the public policy. It is may caused by the political economy in principal relates to the political decision concern on the finance conditions and whoever has right to be granted those finance. Thus it should be answer about the political economy of finance is how the public finance.
\end{abstract}

\section{KEY WORDS}

Finance, political economy, society, state.

Discussions on state budget are closely related with studies of economics and politics which are not often discussed by researchers, neither researchers from economics area whose particular interests are in political economics nor graduates from economic and law majors who are supposedly get involved directly in the budget preparation process. State budget, as the core of governance, always deals with various problems especially the ones related to political process and the budget allocation to fund a number of programs for the society. In developing countries, including Indonesia, budget is still regarded as a formal regulation that gives more benefits for government or institutions, besides in juridical context, it is seen as an already existing regulation. In fact, budget is an integrated part of the national politic for it deals with the policies made by the government, which should be regarded as political investment in which the society have the rights to participate in any of its processes. In addition, budget is also a part of public interest. 
Precise formulation of budget determination should regard the principle of equality. Thus, political economy of the finance closely relates to the attempts that should be made by government to provide appropriate social guarantees, especially for those under the poverty line. There has to be a transparent, accountable, democratic system implemented by the government to prevent any mistrusts from the society toward the government's performances in implementing legal policies that benefit the society. Seen from the political point of view, budget refers to the guarantees given by the government that state budget is allocated for the society, not for funding officials' facilities or privileges.

The political economy of finance involves officials in charge and the capability of the nation in providing adequate social guarantees. Unfortunately, there are indications found in the practice of political economy of finance that it only attempts at achieving short-term targets that benefit only few parties. The regulations in the system indeed give privileges for officials, while the society is given limited access to monitor or participate in the process. Even more, the society often have no idea about the amount of budget allocated for social welfare.

The procedures of determining the state and regional budgets are set by the government in the form of regulations, including the one that guarantees the involvement of the society in the process of budget preparation. Unfortunately, this condition is merely seen as a formal process that has not yet regarded social justice in the governance process. Politically, regulations should be designed prior to conflict managements which should be fairly implemented and applied to anyone without any exceptions. Budget preparation is actually a process of transactional mechanism determination between the government and the society. Consequently, conflicts might appear related to the budget preparation for there are many parties that are fighting for their interests upon the budget. When the political power is dominantly possessed by the elites, the government will be able to propose higher budget to fund their own institutions that might deceive the principle of democracy in the budget preparation.

Similar to the efforts to make precise budget formulation, political economy of finance also relates to the efforts made by the government in providing appropriate social guarantees based on the necessities and the rights of the society. Politic should be regard equality and public participation, where the system of political economy of finance should reflect the equality, justice, participative actions, and governments' responsibilities in enhancing the public service for the society. Involvement of the society in budget preparation is crucial in minimizing the possible conflicts that might occur; besides it also allows the society to participate in the process as individuals and as groups. The society owns the rights to get involved in any political processes run by the government, especially the ones dealing with public interests, for basically, the society holds equal rights and obligations in the politic.

The facts in the field show that society's right to participate in the budget preparation is still limited. State budget often disadvantage the society for it mainly regards the interests of the officials, institutions, or certain parties who participate in the budget preparation, authorization and accountability. It is a fact that various political tricks occur in the preparation of state budget $(A P B N)$, general funds $(D A U)$, special fund $(D A K)$, regional budget $(A P B N)$ and any other budgets. As the result, most of the budgets do not prioritize the improvement of public services. The condition goes worse as political parties get involved in the process in which they try to make the most benefits out of the budget for their own interests.

Those issues reflect the vulnerability of the political economy of finance upon conflict of interest. More importantly, this poor practice does not prioritize the society even though some parties use the name of public interests through the political economy of public interest. There has to be certain actions made to change the paradigm in budget preparation to prioritize the public interest and to create good mechanism through long-term economic analysis that benefits the public. This paper analyses various problems that occurred related to the state budget seen from the economic-politic point of view. 
The essence of budget. To understand the issues on politic and democracy in Indonesia, ones have to see the persons who hold the power. When the power is possessed by politicians who prioritize the society, understand the diversity, and understand the condition of the nation would likely to result more ideal budget plan as expected. As stated by Linz and Stepen (2000), the fluctuation of democracy does not regard social conflicts or economic problems as the variables, yet it includes the behavior of the officials or leaders into the account. The role of politicians reflects the function of the nation and the concept of the politic for the nation.

Comprehending the concept of a nation deals with leading theories on the contemporary nation. First, a nation that applies centralization system in which the central government runs all of national programs, while regional government implement the program in the regional level. Second, a nation that applies decentralization system in which regional government holds the independence and authority to autonomously run the regional management (Kansil, 2001). Indonesia has implemented both systems in the new order era and in the reformation era. In Indonesia, those two systems used to regard the nation as a political tool in which power was autonomously distributed. At the present time, politic is seen as a mean to improve the conditions of the nation and the regions.

The concept of a nation is seen by Russel (1954) as a division of power to put the needs of the society at the top. Centralization system might decrease the capability of the human being (Parma, 2001). In this context, the use of democracy and decentralization systems nurture the positive values of communities that support the national unity, democratic government, independence as the reflection of autonomy, administrative efficiency and socio-economic development (Leemans, 1970).

Structural and fundamental changes that occurred during the reformation era in Indonesia has grown the understanding upon the importance of transparency, accountability, equality, and public participation in socio-economic development that should be put into the paradigm of national development. The distribution of political power, administrative, fiscal and economic development authorities to the regional government is believed to engage stronger public participation in developing their own regions, which is expected to decrease the social gaps among regions in Indonesia. Any asset management such as asset restructure, or the utilization of technology in the management of the assets should be implemented in accordance with general regulations of decentralization system between the central government and the regional government.

Generally, budget is seen as a financial plan that reflects the preferences of programs made by institutions within certain period of time. The definition also applies for the budgets of companies, institutions or other organizations. Meanwhile, in the context of a nation, budget is the statement that explains the income and outcome plans in the future made based on the evaluation of the income and outcome in previous period of time. Regional budget refers to the financial plan in certain region. Budget preparation is one of aspects to consider in financial preparation process as the guidance in managing the financial assets. The preparation and the evaluation of the budget should involve the House of Representatives. Thus, budget also functions as a tool to monitor the performance of the government and at the same time it can be used by stakeholders to make negotiations upon their interests.

This practice commonly occurs in both central government and regional government. Most corruption cases are always related to the budget including the state budget used to fund infrastructure projects, E-KTP, and so on, even more than 400 officials of the House of Regional Representatives, Governors, and city leaders have been involved in budget corruption cases. There are two accusations of corruption crime; individual crime, and collective crime. Individual crime is done individually by a member of the institutions by the help of non-government parties. Whilst, collective crime is done by manipulating the budget to benefit certain individuals through collective decisions made by the institution. The collaborative corruption can be spotted in the increase in officials' salary, facilities such as laptop procurement for the members, additional fund for communication cost, etc while the society is suffering from monetary crisis and the national economy is stated in the poor 
condition. Those conditions can only happen when mutualism synergy occurs between the board of executive and the board of legislative.

There are at least three misconceptions upon budget. First, budget is seen as a complicated and complex problem. In order to understand it, ones have to possess certain capability and certain education degree. It is challenging to change this misconception since the budget itself has certain structure, system and mechanism that can be understood by people with special capability. Unfortunately, (or fortunately?), the access toward documents related to budget is not open for everyone. There are cases in developing countries, including Indonesia, where budget is seen a formal regulation that gives benefits for the government or institutions. Besides, in juridical context, budget is seen as an existing regulation that cannot be changed. Second, people limit the budget to only an aspect dealing with projects funding and other financial resources. Those misconceptions lead the government to neglect the main function of budget for the society. Poor people somehow become the victims of the poor budget management system. Third, people misunderstand that budget is only for the government to monopoly. Up to the present time, the government of Indonesia puts state budget exclusively into their area, without giving access for the society to participate in the process (Fuady, 2002).

Ideally, budget functions as a means of fiscal and management instruments. As a fiscal instrument, budget should be used to determine the fund allocated for procurement of public goods and services. According to the scale of priority, governments are allowed to allocate certain amount of fund for certain expenditures. Another fiscal function of the budget is for the distribution of resources. Using the budget, governments are able to make policies to lessen the social gap among regions, social classes and various sectors in a country. The third function is the stabilization function. When extreme condition occurs, such as when the market price is extremely high or extremely low which might disadvantage some people, governments are allowed to make interventions through the budget system.

One of important aspects to fulfill in determining the budget is the availability of access for the society to participate in any social, political and economic programs. Transparency in the budget management is the key to the implementation of democratic budget management system. The mechanism of democratic political system demands the governments show transparent and open governance (Irianto, 2005).

Some violations occurred in the implementation of political economy of finance, which urge the government to manage the budget in such ways that it gives most benefits for the society. One-sided solutions that give benefit for certain organization are deceits for the society. Syafii (2004) stated that politicians with poor morality deceive the trust given by the society. The society has given the authority for the government to manage civilized social life even though in the society, people with superior political power exist. The system should be implemented in such a way that any political actions are oriented to fulfill the public interests (Suseno, 2003).

The position and the domains of political economy of finance are still debatable among experts. People believe that problems related to budget are governmental, institutional, managerial, political, authoritative, norm-related, ideological, policy-related, market, social and cultural issues and they regard them as short-term political economy of finance issues. The definition and the coverage of political economy of finance system are unclear, creating misconceptions among the society. However, generally, it is believed to be under governments' responsibilities as an aspect to analyzed from the economic-politic point of view. Therefore, political power is an important factor in budget preparation. The problems that occur should motivate the government to employ the system in ways that it benefits the society instead of using it to limit society's participation. In this context, government institutions have the rights to re-formulate their role and functions within their attempts improving social welfare.

Attempts to find the most appropriate formulation of budget should prioritize the budget equality which closely relates with the capability of the nation in providing appropriate social guarantees for the society, especially for poor people. A transparent, accountable, and democratic relationship between government and the society will effectively reduce the doubt 
if the board of executives and legislatives are running the governance well, put the public interest at the top priority, and they are able to give real evidence of the progress to the society. It can be inferred from those facts that it is important to formulate the budget that focuses on creating equality, fairness, higher society participation and better responsibility given by the government in improving the public service for the society.

Unfortunately, the facts show that the practice of budget preparation limits society's participation in the process. The present mechanism system applied in political process in Indonesia is mostly determined by the ethics/moral of the stakeholders. Fights upon individual rights affect procedural mechanism in budget preparation process which at the same time can also be used as the excuses to create mutual synergism that gives more benefits to the stake holders. Bad politic practices are commonly employed to increase the amount of the budgets, including $A P B N, D A U, D A K$ and $A P B D$ as well as other financial aids. The available public services could not yet reached the ideal target; providing excellent service to improve the social welfare.

In the name of social welfare improvement, stake holders tend to only build physical flagship projects in some regions which benefits are still questionable. Some programs were not approached based on real needs analysis of the society that eventually the programs tend to disadvantage the society. Up to this present time, stakeholders measure the development through the development of physical infrastructure, giving an impression that national development is merely monumental, while human capital development is often neglected.

Purwo Santoso (2004) believe that serious problems occur when a nation failed at providing these three aspects; comfort, service and security. These three aspects should be put into consideration in providing social guarantees for the society. The government should create laws and regulations that should be obeyed by the society, while the society receive their civil rights at the same time. The formulation of the regulation also deals with the budget allocated for public service improvement, which amount is set through a long political process that regards the dimension of public rights.

Political economy of finance. Studies of economics and politics propose various recommendations of what state officials are responsible for in relation to their functions. Different insights on this matter remain debatable. Is the government responsible for the determination of what aspects should be included in the budget and should the government find the possible resources to fulfill the necessities related to the determined aspects? Or the determined aspects would be fulfilled in much better way when non-government parties take over the management of the resources? Other questions also appear; Should housing, health, education, social welfare etc be fulfilled by the society themselves or by the nongovernment parties by employing the available resources? Or should they be fulfilled by the government?

The debate also covers various issues which have been discussed in various studies of economics and politics through various approaches. There are two groups of the most appealing approaches. First, aspects or problems that appear out of the self-regulating market. Then, how far is a system that involves market holders who might prioritize their own interests able to fulfill the needs of the society within limited resources? In the modern era, this question is equal to the question about whether political interventions in the national economy improve or hold back the fulfillment of society's necessities.

The second issue deals with problems upon the concept of public agenda. How is the relationship between the fulfillment of public needs and personal needs? Is a nation is meant to fulfill all private necessities of the society, in which a nation should regulate the economic activities, or should a nation intervene the economic activities when the available resources could not fulfill all of the necessities? To what extent is the relevance of private interests to be considered in the determination of public objectives?

Issues about budget should be reviewed from the studies of economics and politics for those fields belong to social disciplines that employ supra-disciplinary approaches beyond the discipline limits. Analysis on any issues related to public policies should directly or indirectly put public interest into the consideration (Uphoff and Ilcham, 1972). Therefore, 
within certain coverage or depth, analysis of economics and politics might tap on various issues from private and organization sectors, as well as both of them. In addition, the analysis can be done within both micro or macro level.

Solichin Abdul Wahab (1999) generally agrees with Uphoff and Ilcham that issues on this matter can be included into the studies of social science, economics, politics that mostly focus on issues related to public politics (as stated in Dye, 1972). As a matter of fact, economy and politic are strongly related to various political decisions determining the supply of goods or public services.

Budget for public sector can be analyzed through three approaches; the theory of public preferences, economic analysis on public politics and economic analysis on institutions.

The theory of public preferences. Generally, the theory of public preference applies various economic methods into the politic domain. As stated by Buchanan (1983:13), this theory mainly applies methods which have been developed up to the advanced analytical level to be implemented in political and government sector, as well as in the studies of politics and public economics.

Even though this definition may seem narrow, yet the implementation of economic methods in the domain of politics triggers a number of problems. The problems might occur due to the failure in aggregating personal preferences into a collective or public preferences. Besides, it is also difficult to coordinate private interests to reach certain public objectives and issues also occur due to the interdependence among different private interests. Those three problems have been discussed in some literatures on the regulations of voting, collective actions and strategic theory.

The theory of public preferences is relatively new compared to other older theories on economics for the contents of this theory are mostly derived from the literatures on public finance in 1950s (Musgrave and Peacock 1958; Musgrave 1959), and some others are the contributions from the conceivers of this theory including; Social Choice and Individual Values by Kenneth Arrow (1951), An Economic Theory of Democracy by Anthony Downs (1957), and The Calculus of Consent by James Buchanan and Gordon Tullock (1962) as well as the one proposed by Mancur Olson in a book entitled The Logic of Collective Action (1965) which has given major contribution in the introduction of the theory of public preferences. This theory itself was introduced by some economists to politicians to help them designing standard procedures of politic studies (including the insights on organizing the interest groups, bureaucratic behaviors, organizational foundation of influence and alliance) within the framework of collective behaviors.

The historical contributions of the theory of public preferences can be seen in a specialized journal (Public Choice) that has certain association (The Public Choice Society). Even though literatures on this field are only available in one journal, the existence of this publication, association and professional conferences consolidate and direct this research theme into a clear focus. The Public Choice Society was established in 1960s in the University of Virgina which was firstly named as the Committee on Non-Market Decision Making (Tollison 1984:3). In 1966, this association released a series of paper namely the Papers on Non-Market Decision Making. In 1968 the name of this committee was changed to The Public Choice. The new name is considered interesting and it reflects the idea that economics is a discipline that talks about market and non-market decision making, while the politics deals with discusses about collective processes and impacts.

Most of research results in this matter define public preferences as the integration of economics methods into the political domain (Mueller 1979: 1; Buchanan 1984:13; Ekelund and Tollison 1986:440) without relating those methods to various impacts in the public domain (see Plott 1976). Studies done by Stiglitz 91988:145 etc) and McLean (1987:9-11) mainly focused on the issues of public domain. In this context, the theory of public preference states that public preference strongly correlates with public inventory. The logic behind this view is that if the impacts of various social processes in the society are not influenced by extern factors, then private decisions are likely to give the expected benefits. The focus of this public preference approach is on the individuals who make decisions and actions. 
Impacts of different decisions made by some individuals are regarded public, collective and undividable. Public is not a group of people who can make choices upon collective behavior as assumed by a theory that collective action is methodologically determined by individuals, as proposed in this public preference theory.

The theory of public preferences also sees individuals, including when they act as members of a political party, interest group, bureaucracy, or when hey act within their capacity as officials, civilians, or as leaders of companies, as the main aspects of the analysis. The main premise of public preference theory is that policy makers (voters, politicians, and individual decision makers (consumers, mediators, producers) tend to show similar behaviors all of those parties prioritize their private interest in the most rational way. Moreover, economic and political decisions are often taken by civilians who are also consumers and voters at the same time. Individuals who buy goods from the market are also the voters in elections (Ekelund dan Tollison 1986:440).

Economic analysis on public policy. Within certain perspective, economic analysis on public policy is a series of plans done after procedures of public preference analysis had been determined. The theory of public preference is a method that combine individual preferences and social welfare. In this part, the researcher assume that the individual preferences had been previously aggregated, and had been checked by decision makers. Thus, decisions makers have to choose the best alternative that likely gives more satisfaction out of some alternatives (the determination of the most preferred alternative involves those who might be affected by the decisions, instead of merely satisfying the decision makers). Hence, even though there might be a strong correlation between the theory of public preferences and economic analysis of public policy, each aspect has different focuses.

In order to understand the alternative policies, some questions might appear; what kinds of questions should be made by an economist? What orientation should be applied? What indicators should be used in the measurement? In this context, the use of neoclassical approach in making economic decisions answers three questions related to the government's coverage, constitutional principles of the government and the most efficient method to achieve the collective objectives. The focus of the explanation presented in this study is on the third point; the most efficient way to achieve the collective objectives, but this paper also proposes some ideas related to the second and the first points.

How far broad is the sphere of politics? Or in another word, where is the limitation between a nation and its market? Those questions raised by Adam Simth (1776) and Hebert Spencer (1843) remain unanswered. Prior to those questions, Herbert Spencer wrote an essay entitled «The Proper Sphere of Government». To answer these questions, economists started from analyzing the individual aspects to the market aspects. Individuals make exchanges in the market by selling and buying goods, services and other productive items. A basic theory of neoclassical principle of economic welfare states that if a market is a perfect competitive market, a set of equilibrium price that will improve the social welfare through exchanges in the market might come true. In this equilibrium state, everyone is in the maximum position. Hence, if ones want to improve their position to higher level of welfare, they will have to disadvantage others. In the market economy, government is only allowed to make intervention in the form of actions that the market failed to do, or actions that are not effectively run by the market. In another word, government takes actions when the market fails. Market power is determined by the specifications, ownership, supply, organization of military power, supply of public goods and externalities, as well as control toward the concentration of economic power (Rhoads, 1985:66).

Economics analysis on institution. North and Thomas have proposed a broad definition of institution, in which institution is defined as «organization among economic units that define and specify various ways to collaborate or to compete against each other» (1973:5). In a separate study, North stated that institutions set certain limitations to direct ones' behavior in the form of rules, regulations and procedures that detect violation, while institutions also regard moral and behavioral values that define certain contours which limit the specification of the rules and regulations besides they also limit the way to implement the rules and regulations (North 1984:8). 
Those definitions see institutions as extern limitations or opportunities for economic agents (= cannot be controlled by individual economic agent). This view allows reader to focus the analysis on the individuals, using several hypotheses; maximizing private gain, and the changeable aspects are only the costs and profits of various alternative actions. Individuals may maximize their personal gain according to the determined distribution system, available resources, utilization of technology and organizational system of the institutions. It implies that the variables used in this context are variables from basic economic equations and institutions or management of institutions as the new variable.

Economic analysis on institutions focuses on how institutions nurture cooperative instrumental behaviors (behaviors to achieve certain goals), decrease or increase the transactional costs, and give clear organizational management in production and exchange activities. It also focuses on the relationship between institutions and efficiency on how institutions facilitate or inhibit the fulfillment of self-oriented interests.

Within this framework, institutions are sets of rules or procedures that determine, ban, or allow certain behaviors. Political institutions have the rights to determine the goods to be exchanged, regulations that apply in the exchange process, and determine the ownership rights that apply upon certain profit or liability. Political aspects of political institution can be seen from the establishment history of the institutions, either or not institutions were created by the nation, besides they can be seen from how the institutions use their power or authorities, including how they apply sanctions in the implementation of certain regulations.

If the use of economic approach to understand the characteristics institutions works better than any sociological approaches, then ones might understand political institutions better when political institutions are compared to the market. Theories on market behavior propose that individuals are likely to fulfill their needs or interests within a situation where there are other people who exchange their alienable goods. The prices or values of alienable goods are determined by the interaction between the rarity of the goods and the choices of other alternative goods. Political institutions also set opportunities and limitations through authoritative polities that influence the costs/expenses.

Those three approaches recommend that within the implementation of political economy of finance, analysis on budget-related issues should put public interests, economic analysis on public policies and economic analysis on institutions at the top priority in order to make sure that the public receives the most benefit of the budget regarding to the fact that the public or society are the ones who have the rights upon the budget.

Conclusion. Generally, budget-related issues are under the responsibility of the government, since the government is in charge to provide public service, equality, and guarantee the public rights. Some politicians and officials take the advantages out of these problems to take personal profits by applying higher fund allocation in the name of public interests. Even in the era of regional autonomy, changes upon the paradigm of budget management and budget essence still occur.

The government should start finding ways to integrate the budget equity into political will of the executive and legislative officials. Essentially, political economy of finance is about how a nation provides appropriate social guarantees for the society upon their basic rights as the consumers of public service. Thus, it is inappropriate to limit the rights of the society upon the budget in the name of the public interests. This way, improvement of the budget management deals with creating certain budget system that regards equality, equity, public participation, and government responsibility in improving the quality of public services.

Furthermore, analysis on the political economy of finance can be administered under social science studies since it is within the coverage of economic-politic studies in which supra-disciplinary approach can be employed. In this field, public issues and policies are the focus of analysis in this field for they are directly and indirectly related to public interests and any public-related policies. Besides, national economy and politic are closely related to any policies or decisions made prior to the budget management and budget allocation. Therefore, it is obvious that analysis on political economy of finance is mainly about how state budget is spent for the society. 


\section{REFERENCES}

1. Annonymous. (2000). Modul Workshop Penganggaran Daerah untuk Anggota DPRD Propinsi DIY. Yogyakarta: IDEA.

2. (2003). Rekaman Proses Workshop Partisipasi Masyarakat dalam Anggaran. Yogyakarta: IDEA.

3. Dahl, R. (2001). Perihal Demokrasi: Menjelajahi Teori dan Praktek Demokrasi secara singkat. Jakarta: YOI.

4. Edi, S. I. ( 2005). Pajak dan demokrasi Negara. Yogyakarta: Pustaka Pelajar.

5. Etzioni, A. (1985). Organisasi-organisasi Modern. Jakarta: UI Press.

6. Franz, M. S. (2003). Etika Politik: Prinsip-prinsip Moral Dasar Kenegaraan Modern. Jakarta: Gramedia.

7. Haryatmoko. (2003). Etika Politik dan Kekuasaan. Jakarta: Penerbit Buku Kompas.

8. James, A. C., \& David, P. L. (1992). Teori-teori Ekonomi Politik. England: Cambridge University Press.

9. Liz \& Stepen. (2000). Political Man The Social Bases of Politics. New York: Doubleday

10. Munir, B. 2003, Perencanaan Anggaran Kinerja. Memangkas Inefisiensi Anggaran daerah. Mataram: Samawa Center.

11. Puro, S. (2004). Dalam Kata Sambutan Menjaring Anggaran Untuk Rakyat. Yogyakarta: Yayasan Tifa\& IDEA.

12. Santoso, P. (2004). Menjaring Anggaran untuk Rakyat. Yogyakarta: Yayasan Tifa-Idea.

13. Siregar, D. (2002). Optimalisasi Pemberdayaan Harta Kekayaan Negara: Peran Konsultan Penilai dalam Pemulihan Ekonomi Nasional. Jakarta: Gramedia Pustaka Utama.

14. Thomas, V., et al. (2001). The Quality of Growth. Translated. Jakarta: Gramedia Pustaka Utama.

15. Wahab, S. A. (1999). Ekonomi Politik Pembangunan: Bisnis Indonesia Era Orde Baru dan ditengah Krisis Moneter. Malang: Brawijaya University Press.

16. Varma, S. P. (2001). Teori Politik Modern. Jakarta: Rajawali Press. 